\title{
SAÚDE NO CÁRCERE FLUMINENSE: ANÁLISE DOS CASOS DE MENINGITE DE 2019
}

\author{
Natália Lucero Frias Tavares ${ }^{1}$ \\ Antonio Eduardo Ramires Santoro ${ }^{2}$
}

\section{Resumo:}

O presente trabalho tem por propósito analisar os episódios de enfermidades e falecimento decorrentes de meningite bacteriana ocorridos no ano de 2019 em unidades prisionais situadas no estado do Rio de Janeiro no Complexo de Gericinó. Analisando a previsão constitucional do direito à saúde, o princípio da intranscendência da pena e a responsabilidade do Estado de prover proteção e assistência àqueles indivíduos em privação de liberdade, pretende-se analisar as posturas adotadas pelos representantes do governo para o tratamento da questão da saúde no cárcere em momentos de crise.

Palavras-chave: Encarceramento; meningite bacteriana; direitos da pessoa presa.

\section{HEALTH INSIDE RIO DE JANEIRO'S PRISON SYSTEM: AN ANALYSIS OF 2019'S CASES OF MENINGITIS}

\begin{abstract}
:
This paper aims to analyze the meningites episodes and deaths that occurred during the year 2019 inside the prison complex called Gericinó Complex that is located in Rio de Janeiro. Dwelling on the right to health, the non transcendence of the criminal conviction principle and the State's obligation to provide assistance in order to ensure and protect inmate's rights, a critical analysis of the acts performed by representatives of the government and administration in regard to prison healthcare will be scrutinized.
\end{abstract}

Keywords: Imprisonment; bacterian meningitis; inmates' rights.

\section{Introdução}

O artigo 196 da Constituição Federal de 1988 dispõe que "a saúde é direito de todos e dever do Estado, garantido mediante políticas sociais e econômicas que visem à redução de doença e de outros agravos e ao acesso universal e igualitário às ações e serviços para sua promoção, proteção e recuperação".

\footnotetext{
${ }^{1}$ Professora Substituta da UFRJ. Professora visitante do programa de pós graduação da ABDCONST/RJ. Doutoranda em Direito pela UFRJ. Mestra em Direito pela Universidade Católica de Petrópolis (UCP). Especialização em Direito Penal, Processo Penal e Criminologia pela UCAM/RJ. Graduada em Direito pela UERJ. Advogada criminalista. Endereço eletrônico <natalialuceroadv@gmail.com>.

${ }_{2}^{2}$ Professor Titular do IBMEC/RJ; Professor Adjunto do PPGD/UFRJ; Professor Adjunto do PPGD/UCP; Pós Doutorado pela Universidade de Coimbra; Doutor e Mestre pela UFRJ; Mestre pela Universidade de Granada; Advogado criminalista. Endereço eletrônico <antoniosantoro@ucp.br>.
} 
Sendo a saúde um direito fundamental inerente a toda e qualquer pessoa, conforme prevê o próprio texto constitucional em diferentes dispositivos, bem como a legislação extravagante, reputa-se inquestionável sua relevância tanto para fins de alocação de investimento quanto priorização no que tange à implementação de políticas públicas.

A despeito da existência e vigência do texto legal, em muitos momentos é possível questionar se sua aplicabilidade de fato abrange a integralidade dos indivíduos da população. Tal questionamento surge no momento em que notícias relativas a surtos de doenças em ambiente prisional vêm a público. Apenas a título de exemplificação é possível mencionar a elevada incidência de sarna, tuberculose e HIV na população carcerária.

Partindo da premissa de que a pena de prisão deve apenas privar o apenado do desfrute irrestrito da liberdade ambulatorial, sem acarretar limitação ou exclusão de sua dignidade humana e tutela dos direitos e garantias fundamentais por parte do Estado, colocase aqui um questionamento: por que o cumprimento de pena privativa de liberdade no Brasil apresenta-se, via de regra, associado a riscos graves à saúde?

Tendo por base fundante a certeza de que a assistência no cuidado e prevenção de doenças é assegurada aos indivíduos que compõem a sociedade brasileira independentemente de suas características pessoais, o presente trabalho tem por objeto central de análise a gestão da saúde no ambiente prisional. Considerando que o indivíduo privado de liberdade passa todo seu tempo sob a tutela direta do Estado, configura um contra-senso o abandono patente da saúde prisional.

Utilizando os princípios limitadores e balizadores da pena, pretende-se, ao longo do texto, trabalhar por intermédio da análise qualitativa as cifras prisionais aliada a um estudo de caso, a maneira como o direito à saúde das pessoas que se encontram em situação de privação de liberdade é ou não afetado em virtude da atribuição do rótulo de "criminoso".

Para transpor a barreira da marginalização decorrente do processo de exclusão que os internos e egressos do sistema prisional sofrem por parte da sociedade, o princípio da intranscendência da pena será utilizado como recurso para aproximação entre estes sujeitos estigmatizados e aqueles que se posicionam de maneira favorável a discursos punitivistas alinhados com os - cada vez mais populares e sempre incorretos - dizeres de "direitos humanos para humanos direitos".

Para fins de ilustração e verificação da validade das premissas apresentadas, optou-se pela análise de caso recente envolvendo o falecimento de internos do sistema penitenciário 
por provável contágio de meningite ocorrido no Complexo Penitenciário de Gericinó, localizado na cidade do Rio de Janeiro.

\section{O encarceramento e a naturalização da desumanização da pessoa presa}

De acordo com as últimas estatísticas oficiais divulgadas pelo Departamento Penitenciário Nacional (2017), mais de 726 mil pessoas encontravam-se privadas de liberdade. Tal quantitativo alçou o país à terceira posição no ranking mundial de maiores populações prisionais. Levantamento mais recente do Banco de Monitoramento de Prisões do Conselho Nacional de Justiça aponta para um contingente prisional de 812.564.

Ainda que isoladamente já seja possível constatar a magnitude desta cifra, a mesma se torna ainda mais alarmante quando se considera que: (1) nem todas as unidades prisionais do país forneceram dados de efetivo carcerário para contabilização; (2) sob a perspectiva dinâmica, considerando que $40 \%$ deste efetivo é composto de presos cautelares, o número de indivíduos que passarão ao longo de um ano pelos muros dos estabelecimentos penais será ainda mais elevado.

\section{GRÁFICO 1 - EVOLUÇÃo DAS PESSOAS PRIVADAS DE LIBERDADE ENTRE 1990 E 2016}

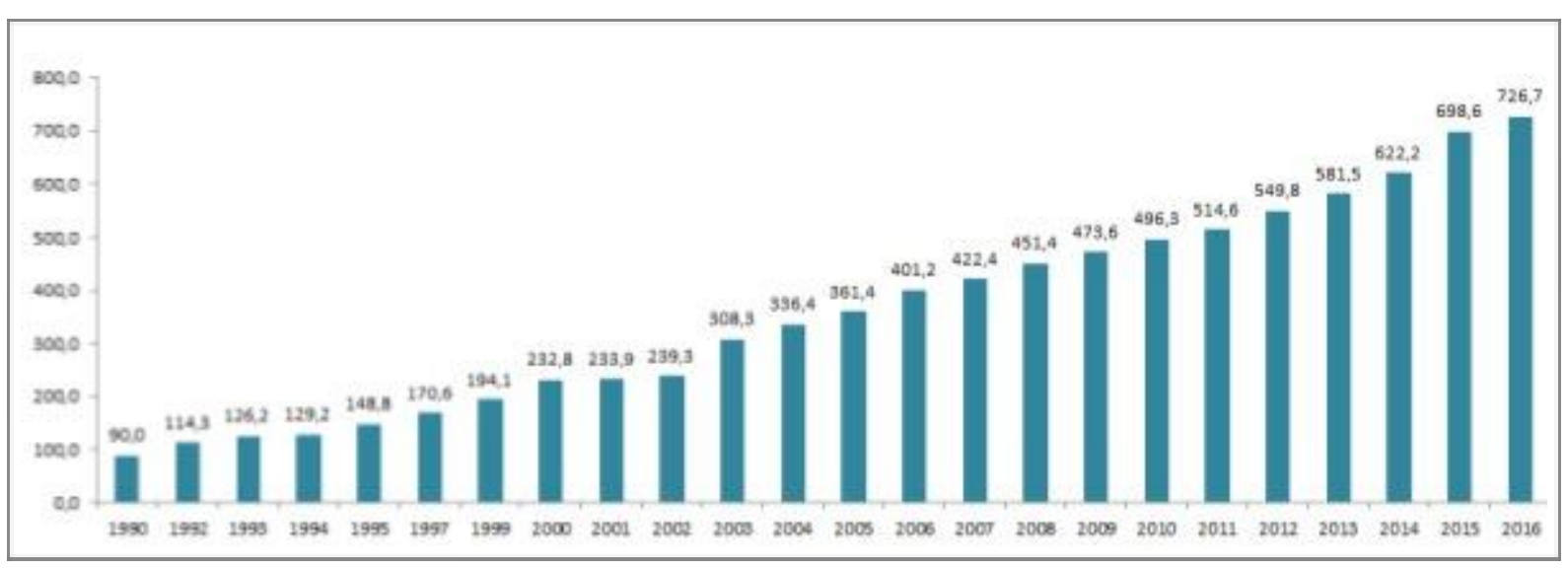

Fonte: Levantamento nacional de informações penitenciárias: INFOPEN atualização - junho de 2016 divulgado pelo Departamento Penitenciário Nacional em dezembro de 2017.

Segundo o último Infopen, apenas $21 \%$ dos estabelecimentos prisionais brasileiros possuem um contingente prisional dentro da capacidade prevista. Dentre os demais, $41 \%$ 
apresentam índices de ocupação entre $101 \%$ e 200\%; outros $20 \%$ apresentam taxas de ocupação que representam entre $201 \%$ e $300 \%$ de sua capacidade total; $5 \%$ das instituições prisionais acomodam efetivo que equivale entre $301 \%$ e $400 \%$ de sua capacidade; enquanto 11\% (leia-se, 155 unidades prisionais) apresentam índice de ocupação superior a 401\% de sua capacidade total (Infopen, 2017, p. 27).

Ou seja, com uma taxa de ocupação média de 197,4\% (Infopen, 2017. p.7), as penitenciárias brasileiras encontram-se superlotadas3, não dispondo de estrutura para abrigar dignamente aquelas pessoas que se encontram sob a tutela penal do Estado.

Entretanto, as mazelas vivenciadas pelas pessoas presas não provocam grande comoção social. Por um conjunto de motivos que não se pretende esgotar aqui, opera-se um processo de invisibilização dos apenados e apenadas que em muito se aproxima do conceito de vida nua delineado por Giorgio Agamben (2014).

Ao tratar dos objetivos do Direito Penal em suas obras, Juarez Cirino dos Santos faz uma clara distinção entre os denominados "objetivos declarados" e os velados (seus efetivos desdobramentos), apontando a grande interseção existente entre este ramo do direito e a desigualdade social. Afirma o autor (SANTOS, 2014. p.10) :

O significado político do controle social realizado pelo Direito Penal e pelo Sistema de Justiça Criminal aparece nas funções reais desse setor do Direito - encobertas pelas funções declaradas do discurso oficial: a criminalização primária realizada pelo Direito Penal (definição legal de crimes e de penas) e a criminalização secundária realizada pelo Sistema de Justiça Criminal constituído pela polícia, justiça e prisão (aplicação e execução de penas criminais) garantem a existência e a reprodução da realidade social desigual das sociedades contemporâneas.

\footnotetext{
${ }^{3} \mathrm{O}$ fenômeno da superlotação carcerária não é novidade no cenário brasileiro: desde a implementação do modelo de política de guerra às drogas na década de '90 (MALAGUTI, 2011.p. 97 e ss) o número de prisões segue em exponencial ascensão. Uma breve análise do perfil das pessoas privadas de liberdade no Brasil ilustra com clareza as repercussões desta estratégia estatal: $26 \%$ dos homens se encontram hoje nos estabelecimentos em decorrência da prática de crimes ligados ao tráfico de drogas; dentre as mulheres, o percentual de encarceramentos decorrentes de práticas ligadas ao comércio de entorpecentes equivale a $62 \%$ do efetivo (Infopen, 2017. p. 43).

Com a manutenção do modelo proibicionista centrado na privação de liberdade, as expectativas quanto às cifras do cárcere são pessimistas: a tendência observada é de que os números de prisões sigam uma crescente, intensificando os problemas já comuns nas unidades (insalubridade, superlotação, etc).
} 
Cirino dos Santos chama atenção para a maneira como o Direito Penal - por meio da criminalização de determinadas condutas - atende aos interesses das classes sociais hegemônicas, assegurando a manutenção de seu status quo.

O processo de criminalização primária traduz claramente as escolhas de política criminal de seu local de inserção em virtude da natureza dos bens jurídicos tutelados: inexistindo em nosso ordenamento qualquer direito absoluto4 ou ordem de importância e prevalência pré-estabelecidas, o ato de conferir proteção penal a determinado bem jurídico não é automático ou óbvio, mas uma construção. Ou seja, no momento que o legislador elabora uma norma prevendo que a lesão a determinado bem jurídico é tão grave a ponto de justificar o exercício do poder punitivo estatal, atua de forma política, criando a diferenciação entre comportamentos desejáveis e indesejáveis (e consequentemente, puníveis).

\section{Saúde no ambiente prisional brasileiro}

\subsection{Os direitos da pessoa privada de liberdade}

O advento da Constituição Federal de 1988 simbolizou real marco de redemocratização após um período de mais de duas décadas de regime ditatorial militar. No título destinado à ordem social, o constituinte originário inseriu expressamente a proteção do direito à saúde.

A redação do artigo 196 da CRFB/88 estabelece que "a saúde é direito de todos $e$ dever do Estado, garantido mediante políticas sociais e econômicas que visem à redução do risco de doença e de outros agravos e ao acesso universal e igualitário às ações e serviços para sua promoção, proteção e recuperação".

A a promoção da saúde não está direcionada apenas à prevenção da doença. A promoção da saúde envolve fatores como a busca pela qualidade de vida, garantindo que a

\footnotetext{
${ }^{4}$ Nenhum direito - ainda que garantido por cláusula pétrea - é absoluto. Deste modo, sempre que diferentes direitos ou garantias colidem não existe uma ordem pré-determinada de prevalência ou sacrifício, demandando a realização de um estudo do caso concreto para determinar qual deverá prosperar naquela hipótese específica. Nem mesmo o direito à vida é absoluto, sendo admitida pena de morte nas hipóteses do inciso XLVII, alínea "a" do art. $5^{\circ}$ da CRFB/88.
} 
população viva em ambiente saudável e protegida contra riscos de adoecimento (WINTER/GARRIDO, 2017. p.6).

Nos estabelecimentos prisionais, as condições precárias de salubridade, superlotação e carência de recursos contribuem para o processo de disseminação de uma pluralidade de doenças que aparecem em incidência superior à observada fora dos limites prisionais.

Para melhor compreender a maneira como a proliferação de doenças em estabelecimentos prisionais repercute sobre pessoas que não se encontram em regime de privação de liberdade, dividiu-se a análise em dois movimentos: os riscos à saúde pública decorrentes da rotatividade da população carcerária e aqueles criados pelo movimento de entrada e permanência de pessoas não presas em ambiente prisional.

Segundo levantamento realizado em parceria pelo Ministério Público do Rio e Janeiro e o Instituto Igarapé (2016) com base nos dados fornecidos pela Secretaria de Administração Penitenciária (SEAP), apenas no estado do Rio de Janeiro houve uma média de cinco mortes de presos por mês entre os anos de 2010 e 2016. Dentre os 442 óbitos computados no período, listam-se 278 mortes decorrentes de doença e 17 falecimentos resultantes de insuficiência respiratória.

Os desdobramentos letais decorrentes de doenças não se limitam ao sistema prisional fluminense, contudo, a falta de transparência dos dados fornecidos pelos levantamentos oficiais (que não assinalam de forma clara os casos de falecimento por doença) impossibilita a realização de um cálculo de proporções. 
TABELA 1 - TAXA DE MORTALIDADE PARA CADA 10 MIL PESSOAS PRIVADAS DE LIBERDADE NO PRIMEIRO SEMESTRE DE 2016 POR NATUREZA DE MORTE E UNIDADE DA FEDERAÇÃO

\begin{tabular}{|c|c|c|c|c|c|c|}
\hline UF & $\begin{array}{c}\text { Óbitos } \\
\text { naturais }\end{array}$ & $\begin{array}{c}\text { Óbitos } \\
\text { criminais }\end{array}$ & $\begin{array}{c}\text { Óbitos } \\
\text { suicidios }\end{array}$ & $\begin{array}{c}\text { Óbitos } \\
\text { acidentais }\end{array}$ & $\begin{array}{c}\text { Óbitos com causa } \\
\text { desconhecida }\end{array}$ & $\begin{array}{c}\text { Total de } \\
\text { óbitos }\end{array}$ \\
\hline AC & 0,0 & 5,6 & 0,0 & 0,0 & 0,0 & 5,6 \\
\hline AL & 3,1 & 4,6 & 0,0 & 0,0 & 0,0 & 7,6 \\
\hline AM & 4,9 & 6,8 & 0,0 & 0,0 & 0,0 & 11,7 \\
\hline AP & 0,0 & 7,5 & 0,0 & 0,0 & 11,2 & 18,7 \\
\hline BA & 7,2 & 2,4 & 3,2 & 0,8 & 4,0 & 17,5 \\
\hline CE & 2,2 & 11,5 & 0,0 & 0,0 & 26,4 & 40,1 \\
\hline DF & 4,0 & 2,7 & 2,0 & 0,0 & 2,0 & 10,6 \\
\hline ES & 5,7 & 0,5 & 0,0 & 0,0 & 0,0 & 6,2 \\
\hline GO & 3,7 & 6,8 & 2,5 & 0,0 & 0,6 & 13,5 \\
\hline MA & 16,9 & 5,2 & 2,6 & 0,0 & 0,0 & 24,7 \\
\hline MG & 5,2 & 4,5 & 1,2 & 0,3 & 0,5 & 11,7 \\
\hline MS & 12,7 & 2,8 & 2,2 & 2,2 & 0,0 & 19,9 \\
\hline MT & 7,7 & 1,0 & 0,0 & 0,0 & 0,0 & 8,7 \\
\hline PA & 6,5 & 10,9 & 0,7 & 1,4 & 4,3 & 23,9 \\
\hline PB & 3,5 & 9,7 & 1,8 & 1,8 & 0,9 & 17,6 \\
\hline PE & 11,3 & 6,7 & 0,6 & 0,6 & 0,6 & 19,7 \\
\hline PI & 17,4 & 17,4 & 0,0 & 2,5 & 0,0 & 37,2 \\
\hline PR & 6,0 & 1,0 & 0,2 & 0,0 & 0,2 & 7,4 \\
\hline RJ & NI & NI & NI & NI & NI & NI \\
\hline RN & 4,6 & 12,6 & 1,1 & 0,0 & 6,9 & 25,3 \\
\hline RO & 7,4 & 2,8 & 0,9 & 0,0 & 0,0 & 11,1 \\
\hline RR & 0,0 & 0,0 & 0,0 & 0,0 & 0,0 & 0,0 \\
\hline RS & 11,2 & 1,8 & 0,0 & 0,6 & 0,6 & 14,2 \\
\hline SC & 11,2 & 0,5 & 0,0 & 0,5 & 0,0 & 12,1 \\
\hline SE & 10,0 & 2,0 & 0,0 & 10,0 & 2,0 & 23,9 \\
\hline SP & 8,7 & 0,4 & 0,7 & 0,0 & 0,4 & 10,3 \\
\hline TO & 8,7 & 11,5 & 5,8 & 0,0 & 0,0 & 26,0 \\
\hline Brasil & $\mathbf{7 , 7}$ & $\mathbf{3 , 0}$ & $\mathbf{0 , 8}$ & $\mathbf{0 , 4}$ & $\mathbf{1 , 6}$ & $\mathbf{1 3 , 6}$ \\
\hline & & & & & & \\
\hline
\end{tabular}

Fonte: Levantamento Infopen - Junho/2016 (2017).

Nota:As amostras analisadas pelos pesquisadoras referem-se apenas ao primeiro semestre do ano de 2016 (01/01/2016 a 30/06/2016). Os óbitos resultantes de doença foram computados na categoria "óbitos naturais". 
Sendo a população prisional brasileira formada por 726.712 pessoas segundo consta no próprio levantamento, ao multiplicar-se os números apresentados na tabela anterior de modo a refletir a quantidade total de mortes no sistema prisional, os resultados obtidos são os seguintes: ocorreram ao menos 988 mortes em ambiente prisional apenas no primeiros semestre de 2016, sendo 559 foram listadas como "naturais" (categoria que também engloba mortes provocadas por doenças).

Segundo o Ministério da Saúde, as doenças que aparecem em maior índice nos estabelecimentos prisionais são a tuberculose (WINTER/GARRIDO, 2017. p7), as doenças sexualmente transmissíveis, dermatoses e hepatites. Os índices de manifestação desta doença nos estabelecimentos prisionais superam consideravelmente àqueles da sociedade em geral.

Para melhorar ilustrar a forma de ocorrência da hipótese de transcendência que aqui pretende-se delinear, é necessário deixar de lado por momentaneamente a questão da saúde nas penitenciárias brasileiras, para tecer comentários sobre a perspectiva dinâmica da população privada de liberdade (SANTORO/TAVARES/GOMES, 2017).

Ao comparar os dados fornecidos pelos levantamentos publicados retroativamente pelo Departamento Penitenciário Nacional, alguns pontos relevantes podem ser apontados: de dezembro de 2015 até junho de 2016, a população carcerária brasileira passou de 698.618 (Infopen referente à dezembro/2015, 2017. p.7) para 726.721(Infopen, 2017. p. 7); no ano de 2015 o sistema teve um total de 469.013 entradas originárias e 353.637 saídas definitivas de interno (não entrando neste computo as transferências e saídas temporárias); só no primeiro semestre de 2016, o número de ingressos foi 266.133 contra 193.789 saídas.

Mesmo não contendo dados a respeito de todas as movimentações ocorridas no sistema prisional, a mera constatação do fluxo de entradas e saídas acima listados permite enxergar que analisar o número de pessoas que sofreram privação de liberdade no Brasil ao longo de determinado período não se resume à cifra do número de internos, sendo necessário acrescentar ao cálculo todos aqueles que por ali passaram.

Levando em conta apenas os números oficiais do Depen, o número de pessoas que estiveram no cárcere brasileiro apenas no primeiro semestre de 2016 equivale ao somatório de 
permanências e saídas, chegando a um total de 920.501. Já o somatório dos números apurados durante o ano inteiro de 2015 chega a um total de 1.052.255 pessoas5.

Uma das práticas que contribui ativamente para o agravamento desse risco é o uso da prisão provisória pelo Poder Judiciário brasileiro. Considerando que 40\% (Infopen, 2017. p.13) desses indivíduos estão presos provisórios, inexiste contra eles qualquer certeza de condenação, sendo sua manutenção em ambiente prisional contrária ao modelo traçado pelo constituinte originário que tem em suas bases a presunção de inocência e a liberdade como regra.

A inserção em ambiente prisional de pessoas que não necessariamente serão condenadas ao cumprimento de uma pena privativa de liberdade, causa os seguintes desdobramentos: (i) coloca em ambiente insalubre e inseguro indivíduos que, segundo as normas legais vigentes, deve ser considerado presumidamente inocente; (ii) agrava o problema da superlotação carcerária; (iii) provoca um aumento da rotatividade da população carcerária; (iv) aumenta os riscos de disseminação de doenças também no exterior dos presídios, funcionando os egressos como uma espécie de vetores.

Também durante a realização de atividades laborativas extramuros, saídas temporárias e deslocamento do interno para comparecimento a fóruns, delegacias e afins se opera esta interação entre internos e sociedade externa.

Feitos esses esclarecimentos introdutórios sobre a relação entre população dinâmica, fluxo de saída de pessoas das penitenciárias e risco de proliferação de doenças, colocam-se alguns esclarecimentos. Primeiramente, não se está defendendo em hipótese alguma a permanência da privação de liberdade como medida assecuratória do direito à saúde da coletividade, mas defendendo a necessidade de oferecer condições de higiene e saúde adequadas no âmbito dos estabelecimentos prisionais para que as doenças que ali se proliferam sejam tratadas e prevenidas.

\footnotetext{
${ }^{5}$ Não havendo dados que permitam verificar com exatidão o número de egressos que saíram do cárcere mas foram presos novamente no curso do mesmo ano, é possível que esses números sejam incompatíveis com a realidade fática.
} 
Quanto à rotatividade populacional nos confins prisionais, o que se propõe como alternativa imediata e viável é reduzir de forma drástica a permanência de presos provisórios nestes locais. Para isso, medidas como a realização de audiências de custódia, isenção do pagamento de fiança e colocação de indivíduos em prisão albergue domiciliar são só algumas das alternativas já existentes e implementadas (timidamente) no Brasil.

De forma geral, aduz-se que a estrutura prisional hoje existente atenta contra o princípio da pessoalidade da pena por ferir o direito à saúde de pessoas estranhas ao direito penal em decorrência das deploráveis condições de lotação, higiene e salubridade em que são acondicionadas as pessoas presas.

Não obstante os riscos de aumento da disseminação de doenças que podem ocorrer em virtude da rotatividade da população prisional, a proteção da saúde pessoas não privadas de liberdade também pode ser atingida em razão da forma de estruturação do próprio modelo prisional.

Para que uma penitenciária funcione, é necessário que se tenha não apenas uma estrutura física adequada, mas também mão de obra para realizar as diferentes atividades que ali se tem de desenvolver, como: cuidar da segurança, oferecer tratamento médico, gerir a parte administrativa, etc. Ou seja, permanecem no interior dos estabelecimentos prisionais tanto as pessoas privadas de pena quanto aquelas que ali trabalham.

De acordo com o último levantamento, entre funcionários efetivos (75\%), comissionados $(2 \%)$, terceirizados $(5 \%)$ e temporários $(18 \%)$, havia um total de 105.215 pessoas trabalhando na ativa em 30/06/2016 (Infopen, 2017, p. 46 e 47).

As doenças contagiosas não diferenciam indivíduos com base nas informações constantes de sua folha de antecedentes criminais, sendo os funcionários expostos a quase tanto risco ${ }^{6}$ de contágio de doença quanto os internos.

\footnotetext{
${ }^{6}$ Não se pode afirmar que o nível de exposição dessas pessoas se iguala em virtude da permanência dos funcionários no local se operar apenas durante seus turnos de trabalho. Ademais, a ocorrência de contato físico dos agentes com presos doentes se dá de maneira mais branda, uma vez que não permanecem no interior de celas superlotadas e não partilham do uso das dependências reservadas aos internos.
} 
Além dos agentes penitenciários, outras pessoas ingressam diariamente em penitenciárias pelo país, parte delas a trabalho (como é o caso de advogados, juízes, assistentes sociais, pastores, voluntários, etc), enquanto outras o fazem para visitar seus companheiros, parentes e amigos privados de liberdade.

Segundo o Levantamento do MP e Instituto Igarapé citado anteriormente, ainda que no Rio de Janeiro haja presídios em dez municípios, os estabelecimentos recebem visitantes de todas as 92 cidades do estado. De acordo com os pesquisadores do Igarapé, para as quase 51 mil privadas de liberdade no Rio de Janeiro em 2016, havia 80 mil visitantes cadastrados.

O descaso com as condições de manutenção do sistema prisional atinge diretamente todas as pessoas que por lá passam, oferecendo riscos à saúde (e à vida) dos mesmos, configurando mais um tipo de transcendência dos efeitos da condenação. Assim como mencionado no item anterior, a melhoria nas condições prisionais proporciona benefícios não apenas à pessoa presa, mas à sociedade de modo integral.

Ao apresentar em sua obra "Direito penal brasileiro: primeiro volume - Teoria Geral do Direito Penal" o conceito de princípio da intranscendência da pena, Zaffaroni, Batista, Alagia se Slokar fazem expressa menção a alguns dos tipos de transbordamentos que decorrem do mero exercício do poder punitivo:

o Estado de polícia estende a responsabilidade a todos que cercam o infrator, pelo menos por não terem denunciado sua atividade, e considera sua família perigosa, porque seus membros podem vingá-lo. Tais características se acentuam nos delitos que afetam a existência do estado, que no estado de polícia se confunde com o governo. Por isso, por meio do terror incentiva a delação e consagra a corrupção de sangue. No estado de direito a responsabilidade penal deve ser individual e não pode transcender a pessoa do delinqüente. Daí o fato de nossa Constituição prever que "nenhuma pena passará da pessoa do condenado" (art.5\%, inc. XLV CR). Entretanto, essa transcendência do poder punitivo na direção de terceiros é, de fato, inevitável: a comunicação, o conhecimento, a estigmatização, a queda dos rendimentos etc., são todos efeitos que inevitavelmente alcançam a família do simples acusado e mesmo outras pessoas. Nossa legislação contém 
poucos dispositivos no sentido de atenuá-los, como, por exemplo, o auxílioreclusão, de natureza previdenciária (art. 80, lei no. 8213, de 24.jul.91). Um efeito transcendente de prisonização - sem embargo da tímida previsão legal da visita íntima (art. 40, inc. X, LEP), na prática subordinada à maior ou menor liberalidade da administração - é a privação de relações sexuais, que deixa ao cônjuge ou companheiro não-institucionalizado a opção entre abstinência ou dissolução do vínculo afetivo (2015. p.232)

\subsection{Os impactos da saúde carcerária na sociedade}

Também chamado de princípio da personalidade ou intranscendência da pena, $\mathrm{o}$ princípio da pessoalidade encontra-se consagrado no ordenamento no artigo $5^{\circ}$, inciso XLV da CRFB/88, gozando de status de cláusula pétrea. Dispõe a redação do referido dispositivo que "nenhuma pena passará da pessoa do condenado, podendo a obrigação de reparar o dano e a decretação do perdimento de bens ser, nos termos da lei, estendidas aos sucessores e contra eles executadas, até o limite do valor do patrimônio transferido".

Inserido no ordenamento brasileiro desde a Constituição de 18247, é o princípio da pessoalidade da pena que assegura a todos a certeza de que a punição proveniente do cometimento de um ilícito repousará apenas sobre os ombros de quem concorreu para a prática da violação.

A análise do princípio da intranscendência da pena proposta no presente estudo não pretende se deter apenas ao aspecto objetivo atingidos por tal previsão, qual seja: a imposição de pena apenas contra quem seja considerado responsável por determinada prática delituosa.

\footnotetext{
${ }^{7}$ Durante a vigência das Ordenações Filipinas, admitia-se que a punição ultrapassasse a figura do autor do delito, podendo a punição se estender a seus familiares. Um exemplo famoso na história brasileira é o da condenação imposta a Joaquim José da Silva Xavier, popularmente conhecido como Tiradentes. A sentença condenatória determinava: "Portanto condenam ao réu Joaquim José da Silva Xavier, por alcunha o Tiradentes, alferes que foi da tropa paga da Capitania de Minas, a que, com baraço e pregão, seja conduzido pelas ruas públicas ao lugar da forca, e nela morra morte natural para sempre, e que depois de morto lhe seja cortada a cabeça e levada a Vila Rica, onde no lugar mais público será pregada em um poste alto, até que o tempo a consuma, e o seu corpo será dividido em quatro quartos, e pregados em postes, pelo caminho de Minas, no sítio da Varginha e das Cebolas, onde o réu teve a suas infames práticas e os mais nos sítios de maiores povoação, até que o tempo também os conota, declaro o réu infame, e seus filhos e netos tendo-os, e os seus bens aplicam para o Fisco e Câmara Real, e a casa em que vivia em Vila Rica será arrasada e salgada, para que nunca mais no chão se edifique, e não sendo própria será avaliada e paga ao seu dono pelos bens confiscados, e no mesmo chão se levantará um padrão pelo qual se conserve em memória a infâmia deste abominável réu”.
} 
Na realidade, o foco central de análise não é a decisão condenatória, mas sim a observância do princípio da pessoalidade durante o curso do cumprimento de pena.

Assume-se que a simples adoção do modelo de política de segurança público fundado mormente na aplicação de pena privativa de liberdade acaba por produzir efeitos que reverberam.

\section{Análise de caso: meningite no cárcere fluminense}

O presente artigo não se apresenta com a pretenção de promover um estudo aprofundado sobre enfermidades ou mesmo o funcionamento do sistema imunológico humano, contudo, com o propósito de facilitar a compreensão do leitor acerca das alternativas que se pretende propor para minorar possíveis danos a direito fundamental, faz-se mister uma incidental da temática.

Visando ofertar detalhes relevantes sobre o caso selecionado para análise, este capítulo trará informações relevantes a respeito da meningite, doença que hoje figura como possível ameaça aos internos do sistema penitenciário fluminense, seus familiares e demais indivíduos que transitam pelos muros do Complexo de Gericinó.

\subsection{Considerações e informações relativas à enfermidade}

Para iniciar a análise a respeito dos procedimentos implementados no Complexo de Gericinó (RJ) na tentativa de conter um possível surto de meningite, faz-se necessária a exposição de algumas informações relevantes sobre esta enfermidade e o corpo humano.

As meninges são membranas que envolvem o encéfalo ${ }^{8}$ e a medula espinhal que passa pelo interior da coluna vertebral. As três camadas que compõem as meninges são chamadas dura-máter, aracnoide e pia-máter 9 .

\footnotetext{
${ }^{8} \mathrm{O}$ encéfalo é composto pelo cérebro, bulbo e cerebelo.

${ }^{9}$ Entre as camadas pia-máter e aracnoide circula o líquido cefalorraquidiano (LCR), também chamado de líquor. É através da análise desse líquido que será feito o diagnóstico da meningite e possibilitada a identificação do agente que lhe deu causa.
} 
Conforme pode-se depreender a partir da análise da própria formação do vocábulo, a meningite é uma infecção dessas membranas que recobrem o cérebro. A doença afeta toda a região, dificultando o transporte de oxigênio às células do corpo.

Uma pluralidade de agentes infecciosos pode provocar a ocorrência de processos inflamatórios das meninges, sendo possível dividi-los em duas principais categorias: bacterianas ou virais. A relevância desta classificação dos agentes causadores se torna evidente no momento de análise das medidas profilácticas cabíveis. Geralmente os casos de meningite são associados a processos virais.

A meningite bacteriana, embora menos recorrente que a viral, apresenta maior risco para o paciente, com taxa de morte de $20 \%$. Dentre os possíveis culpados pela meningite bacteriana, o meningococo aparece como agente mais frequente.

Ainda que a gravidade do processo infeccioso e o risco concernentes à meningite bacteriana sejam mais gravosos que àqueles da meningite viral, o ponto positivo da primeira é a maior facilidade para implementação de medidas preventivas. Isto ocorre em virtude da estrutura das bactérias proporcionarem maior facilidade para realização dos processos mapeamento e inocuização, podendo este último decorrer de campanhas de vacinação.

No que se refere a medidas destinadas à prevenção do contágio dessa enfermidade, a página eletrônica mantida pelo Instituto de Tecnologia em Imunobiológicos - BioManguinhos (2014), vinculado à Fiocruz, menciona:

"Diversas medidas de controle são essenciais para prevenir epidemias de meningite. As principais são: o diagnóstico precoce com a internação de pacientes com sintomas da doença; a vacinação das pessoas em contato muito próximo com enfermos (especialmente dentro do mesmo domicílio); e a vacinação das pessoas com maior risco de adquirir a doença, como as submetidas à retirada cirúrgica do baço (esplenectomizados), as portadoras de disfunção do baço (asplenia funcional da anemia falciforme, da talassemia) ou aquelas com deficiências de imunoglobulinas e do complemento.”

Vale ressaltar que a realização de campanhas de vacinação dirigidas aos grupos em maior risco de contágio apresenta-se, portanto, como medida indispensável para salvaguarda dos direitos à vida e à saúde dos indivíduos.

3.2 Óbitos em ambiente prisional e abordagem prática adotada pela Secretaria da Administração Penitenciária do Rio de Janeiro

Revista de Criminologias e Políticas Criminais | e-ISSN: 2526-0065 | Belém | v. 5 | n. 2 |

p. 82 - 98 | Jul/Dez. 2019. 
Superadas as considerações iniciais, parte-se para o propósito central: análise dos casos de contágio de meningite bacteriana por parte de internos do sistema prisional fluminense e óbitos deles decorrentes.

Em abril do corrente ano, foi noticiado por sites de grande acesso e alcance a suspeita de que uma morte ocorrida dentro de unidade prisional situada no Rio de Janeiro. Após uma análise inicial, aventou-se possibilidade de que o falecimento decorreria de complicação posterior à contração de meningite bacteriana por parte de pessoa privada de liberdade não identificada nas comunicações e reportagens (BARBOSA, 2019). Em seguida, outros possíveis enfermos foram identificados e colocados em regime de quarentena (isolamento).

Após a ocorrência do primeiro óbito resultante de possível caso de meningite na Cadeia Pública Roberto Rocha ${ }^{10}$, a Secretaria de Administração Penitenciária se manifestou através da seguinte nota:

"A Secretaria de Estado de Administração Penitenciária (SEAP) informa que vem acompanhando desde o dia 8, dois casos suspeitos de meningite bacteriana causando a morte de dois internos da unidade Paulo Roberto Rocha, no Complexo de Gericinó. Foram coletadas amostras e estão sendo aguardados resultados de exames. A Seap, através de sua coordenação de saúde com o apoio Secretaria de Estado de Saúde e da Secretaria Municipal de Saúde, já está tomando todas as providências cabíveis. Os 1.750 internos da unidade, assim como os servidores que tiveram contatos com os presos estão recebendo quimioprofilaxia. Visitas e qualquer saída de presos da unidade foram suspensas temporariamente em caráter emergencial. Dez presos foram isolados para que sejam feitas coletas de sangue na Unidade de Pronto Atendimento (UPA) de Gericinó." (GIMENEZ, 2019)

Além da nota divulgada, a orientação veiculada pelos responsáveis pela Secretaria em meios televisivos foi no sentido de dissuadir visitantes, familiares e o público em geral de se dirigir às unidades prisionais situadas no Complexo de Gericinó de modo a reduzir os riscos de contágio. Durante alguns dias as visitas ao local foram suspensas pela Secretária.

No mesmo período, representantes da $\mathrm{OAB} / \mathrm{RJ}$ manifestaram sua insatisfação diante dos baixíssimos índices de inocuização dos internos do sistema prisional e de superlotação prisional, fator que contribui ativamente para o agravamento da ocorrência de doenças (especialmente daquelas transmitidas pelo ar e contato) no cárcere.

\footnotetext{
${ }^{10} \mathrm{Na}$ nota publicada no dia 10/04/2019, a SEAP/RJ não informou nenhum dos dados do interno falecido
} 
Como se buscou ilustrar no subcapítulo anterior, os casos em que a inflamação das meninges decorre de processo bacteriano são os mais facilmente evitáveis. Para este fim, medidas profiláticas de baixa complexidade como a vacinação teriam o condão de resguardar e efetivar não apenas o respeito ao direito à saúde da pessoa privada de liberdade, como também minorariam os riscos à saúde da sociedade em geral, uma vez que o fluxo de entrada e saída do Complexo de Gericinó é considerável.

\section{Considerações finais}

Embora a privação de liberdade ocupe posição inequívoca de destaque e aceitação majoritária por parte da sociedade brasileira, a mesma apenas pode ser aplicada em conformidade com os limites estabelecidos de maneira clara pela legislação vigente.

Ainda que a alusão a argumentos contrários ao expansionismo penal e naturalização (inadequada) do uso da pena de prisão pareça indispensável neste momento histórico atual, objetivando manter estrita referência ao recorte ora proposto, apresenta-se aqui uma clara crítica à maneira como a prevalência das noções arcaicas de aproximação de pena à ideia de penitência e sofrimento ainda se sustenta. Tal visão, além de equivocada é incompatível com um modelo de sociedade democrática, acaba por autorizar tacitamente a inércia estatal ante a proteção e efetivação dos direitos das pessoas privadas de liberdade.

A despeito das noções de neutralização decorrentes do conceito de prevenção geral negativa, a prisão não é (ou, ao menos, não deveria ser) sinônimo de risco à vida ou à saúde da pessoa presa.

Desta feita, considerando o estado de grave vulnerabilidade em que se encontra a pessoa privada de liberdade e a responsabilidade que recai sobre os ombros de Estado de zelar por estas pessoas de quem retira a liberdade ambulatorial (e tantos outros direitos), é inadmissível o abandono e parca assistência dispensados a esta questão. O respeito e atenção à saúde da população prisional merece posição de destaque não apenas pelos possíveis impactos que doenças do cárcere podem gerar na saúde da sociedade em geral (tratando-se de hipótese de transcendência da pena), mas sim por tratar-se, antes de mais nada, de condição para a manutenção de uma existência minimamente digna daqueles indivíduos aprisionados.

Por derradeiro, cumpre ressaltar que a atenção à saúde da pessoa privada de liberdade poderia apresentar melhores resultados tanto em relação a custos quanto efetividade 
da proteção se medidas de profilaxia e redução do contingente prisional fossem efetivamente adotadas.

\section{Bibliografia}

BARBOSA, Filipe. Após morte e casos de meningite em presídios no RJ, servidores denunciam negligência na imunização. In.: https://g1.globo.com/rj/nortefluminense/noticia/2019/06/12/apos-morte-e-casos-de-meningite-em-presidio-no-rjservidores-denunciam-negligencia-na-imunizacao.ghtml

BRASIL. Departamento Penitenciário Nacional. Levantamento Nacional de Informações Penitenciárias: INFOPEN Mulheres Junho de 2014. Disponível em: <http://bit.ly/infopenmulheres>. Acesso em: 6 outubro 2017.

CIRINO DOS SANTOS, Juarez. Direito Penal - Parte Geral. $6^{a}$ Ed atualizada e ampliada. Curitiba: ICPC Cursos e Edições, 2014.

GARRIDO, Rodrigo Grazinoli; RODRIGUES, Eduardo Leal. O Banco de Perfis Genéticos Brasileiro Três Anos após a Lei no 12.654. In Revista de Bioetica y Derecho, v. 35, p. 94107, 2015.

GIMENEZ, Elza. Preso morre com suspeita de meningite em cadeia do Rio; dois casos são investigados, in: https://g1.globo.com/rj/rio-de-janeiro/noticia/2019/04/10/preso-morre-comsuspeita-de-meningite-em-cadeia-do-rio-dois-casos-sao-investigados.ghtml

INSTITUTO DE TECNOLOGIA EM IMUNOBIOLÓGICOS. Meningite AC: sintomas, transmissão e prevenção. In: https://www.bio.fiocruz.br/index.php/meningite-a-c-sintomastransmissao-prevencao

TAVARES, Juarez. PRADO, Geraldo. O Direito Penal e o Processo Penal no Estado de Direito: análise de casos. Florianópolis: Empório do Direito, 2016.

VALENCA, Mariana Soares; CEZAR-VAZ, Marta Regina; BRUM, Clarice Brinck; SILVA, Pedro Eduardo Almeida da. O processo de detecção e tratamento de casos de tuberculose em um presídio. Ciência saúde coletiva [online]. 2016, vol.21, n.7, pp.2111-2122. Disponível em: http://dx.doi.org/10.1590/1413-81232015217.13822015. Acesso em 03 de janeiro de 2018.

WINTER, Debora Carollo de Almeida; GARRIDO, Rodrigo Grazinoli. A tuberculose no cárcere: um retrato das mazelas do sistema prisional brasileiro. In: www.researchgate.net/publication/319292347_A_TUBERCULOSE_NO_CARCERE_UM_R ETRATO_DAS_MAZELAS_DO_SISTEMA_PRISIONAL_BRASILEIRO . Acesso em 3 de janeiro de 2018.

ZAFFARONI, Eugenio R; BATISTA, Nilo; ALAGIA, Alejandro; SLOKAR, Alejandro. Direito Penal Brasileiro: primeiro volume - Teoria Geral do Direito Penal. $4^{\mathrm{a}}$ ed. Rio de Janeiro: Revan, 2011. 